\title{
Antitumor Effect of the Essential Oil from the Leaves of Croton matourensis Aubl. (Euphorbiaceae)
}

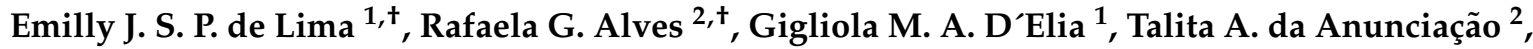 \\ Valdenizia R. Silva ${ }^{2}$, Luciano de S. Santos ${ }^{2}$, Milena B. P. Soares ${ }^{2,3}$, Nállarett M. D. Cardozo ${ }^{4}$, \\ Emmanoel V. Costa ${ }^{5}$, Felipe M. A. da Silva ${ }^{5}$, Hector H. F. Koolen ${ }^{1, *}$ and Daniel P. Bezerra ${ }^{2, * \mathbb{D}}$ \\ 1 Metabolomics and Mass Spectrometry Research Group, Amazonas State University (UEA), \\ Manaus, Amazonas, 690065-130, Brazil; emillyjulianasales@gmail.com (E.J.S.P.d.L.); \\ gigliolamayara@gmail.com (G.M.A.D.) \\ 2 Gonçalo Moniz Institute, Oswaldo Cruz Foundation (IGM-FIOCRUZ/BA), Salvador, \\ Bahia, 40296-710, Brazil; rafalves09@gmail.com (R.G.A.); tali.andrade36@gmail.com (T.A.d.A.); \\ valdeniziar@gmail.com (V.R.S.); luciano.biomed@gmail.com (L.d.S.S.); milena@bahia.fiocruz.br (M.B.P.S.) \\ 3 Center of Biotechnology and Cell Therapy, Hospital São Rafael, Salvador, Bahia, 41253-190, Brazil \\ 4 Amazonia Museum (MUSA), Manaus, Amazonas, 69099-415, Brazil; nallarett.davila@gmail.com \\ 5 Department of Chemistry, Federal University of Amazonas (UFAM), Manaus, Amazonas, 69077-000, Brazil; \\ emmanoelvc@gmail.com (E.V.C.) felipesaquarema@bol.com.br (F.M.A.d.S.) \\ * Corresponding: hkoolen@uea.edu.br (H.H.F.K.); danielpbezerra@gmail.com (D.P.B.); \\ Tel. + 557131762272 (D.P.B.) \\ + These authors contributed equally.
}

Received: 31 October 2018; Accepted: 12 November 2018; Published: 14 November 2018

\begin{abstract}
Croton matourensis Aubl. (synonym Croton lanjouwensis Jabl.), popularly known as "orelha de burro", "maravuvuia", and/or "sangrad'água", is a medicinal plant used in Brazilian folk medicine as a depurative and in the treatment of infections, fractures, and colds. In this work, we investigated the chemical composition and in vitro cytotoxic and in vivo antitumor effects of the essential oil (EO) from the leaves of C. matourensis collected from the Amazon rainforest. The EO was obtained by hydrodistillation using a Clevenger-type apparatus and characterized qualitatively and quantitatively by gas chromatography coupled to mass spectrometry (GC-MS) and gas chromatography with flame ionization detection (GC-FID), respectively. In vitro cytotoxicity of the EO was assessed in cancer cell lines (MCF-7, HCT116, HepG2, and HL-60) and the non-cancer cell line (MRC-5) using the Alamar blue assay. Furthermore, annexin V-FITC/PI staining and the cell cycle distribution were evaluated with EO-treated HepG2 cells by flow cytometry. In vivo efficacy of the EO (40 and $80 \mathrm{mg} / \mathrm{kg} /$ day) was demonstrated in C.B-17 severe combined immunodeficient (SCID) mice with HepG2 cell xenografts. The EO included $\beta$-caryophyllene, thunbergol, cembrene, $p$-cymene, and $\beta$-elemene as major constituents. The EO exhibited promising cytotoxicity and was able to cause phosphatidylserine externalization and DNA fragmentation without loss of the cell membrane integrity in HepG2 cells. In vivo tumor mass inhibition rates of the EO were $34.6 \%$ to $55.9 \%$. Altogether, these data indicate the anticancer potential effect of $C$. matourensis.
\end{abstract}

Keywords: Croton matourensis; Croton lanjouwensis; antitumor; apoptosis; HepG2

\section{Introduction}

The genus Croton (family Euphorbiaceae) contains approximately 1300 species that are found in tropical and subtropical regions of the world [1]. Plants from this genus have been used in the folk medicine to treat cancer, which include C. palanostigma Klotzsch [2,3], C. lechleri Müll. Arg. [4] and C. tiglium L. [5]. Moreover, numerous plants belonging to this genus have been reported with cytotoxic 
and antitumor potentials, including C. palanostigma Klotzsch [2], C. regelianus Müll. Arg. [6], C. lechleri Müll. Arg. [7], C. urucurana Baill. [8], C. betulaster Müll. Arg. [9], C. tiglium L. [10] and C. crassifolius Geiseler [11].

Croton matourensis Aubl. (synonym Croton lanjouwensis Jabl.) is a tree widely spread in the Amazon rainforest and in some regions of Central America (Panama). In Brazil, it is popularly known as "orelha de burro", "maravuvuia", and/or "sangrad'água", and is used in folk medicine as a depurative and in the treatment of infections, fractures, and colds [12-15]. However, only few research papers are found for this species [16-19]. $\alpha$-Pinene, elemecine, $\alpha$-phellandrene, $p$-cymene, linalool, and $\beta$-caryophyllene were found as the main constituents in the essential oil (EO) from the leaves, fruit, inflorescence, and bark of C. matourensis collected from the Brazilian Amazon rainforest [16,17]. Additionally, the seco-labdane diterpene named maravuic acid was isolated from the bark of C. matourensis [18]. More recently, the chemical composition and cytotoxic activity of the EO from the leaves of C. matourensis collected in Venezuela were reported [19], in which fenchyl acetate, methyleugenol, isoelemicine, elemicine, spathulenol, and valencene were found as main constituents, and cytotoxic potential was observed in LoVo (human colon carcinoma) and HeLa (human cervical cancer) cell lines [19]. However, in vivo antitumor properties have not been investigated. In this work, we investigated the chemical composition, in vitro cytotoxicity, and in vivo antitumor effect of the EO obtained from the leaves of C. matourensis collected from the Amazon rainforest.

\section{Results}

\subsection{Chemical Composition of the Essential Oil}

The EO recovery from the leaves of C. matourensis was $0.34 \pm 0.03 \%(w / w)$ and its chemical composition is presented in Table 1. The terpenoid class fully dominated the EO sample composition, in which, sesquiterpenes were the main representatives $(46.53 \%)$, followed by diterpenes $(26.94 \%)$, and monoterpenes (25.02\%). Among them, 42 (representing 90.00\% of the EO) were identified based on their retention indexes and mass spectral-fragments. The major compounds in the EO were $\beta$-caryophyllene $(12.41 \pm 1.02 \%)$, thunbergol $(11.74 \pm 1.11 \%)$, cembrene $(7.12 \pm 0.55 \%), p$-cymene $(5.05 \pm 0.49 \%)$, and $\beta$-elemene $(4.94 \pm 0.35 \%)$.

Table 1. Chemical composition of the essential oil from the leaves of Croton matourensis.

\begin{tabular}{cccccc}
\hline Number & Compound & $\begin{array}{c}\text { Retention } \\
\text { Time (min) }\end{array}$ & $\begin{array}{c}\text { RI } \\
\text { Theo. }\end{array}$ & $\begin{array}{c}\text { RI } \\
\text { Exp. }\end{array}$ & $\begin{array}{c}\text { Proportion } \\
\text { Area (\%) }\end{array}$ \\
\hline 1 & $\alpha$-thujene & 5.28 & 924 & 924 & $1.99 \pm 0.21$ \\
2 & $\alpha$-pinene & 5.48 & 932 & 931 & $3.41 \pm 0.34$ \\
3 & sabinene & 6.60 & 969 & 969 & $0.11 \pm 0.03$ \\
4 & $\beta$-pinene & 6.72 & 974 & 974 & $0.25 \pm 0.04$ \\
5 & $\beta$-myrcene & 7.11 & 988 & 987 & $0.26 \pm 0.04$ \\
6 & $\alpha$-phellandrene & 7.59 & 1002 & 1002 & $3.90 \pm 0.28$ \\
7 & $\alpha$-terpinene & 8.02 & 1014 & 1014 & $0.54 \pm 0.30$ \\
8 & p-cymene & 8.31 & 1020 & 1020 & $5.05 \pm 0.49$ \\
9 & limonene & 8.46 & 1024 & 1023 & $1.85 \pm 0.18$ \\
10 & eucalyptol & 8.57 & 1026 & 1026 & $0.15 \pm 0.02$ \\
11 & $\beta$-ocimene & 9.18 & 1032 & 1032 & $0.13 \pm 0.02$ \\
12 & $\gamma$-terpinene & 9.62 & 1054 & 1054 & $2.02 \pm 0.23$ \\
13 & terpinolene & 10.85 & 1086 & 1086 & $2.15 \pm 0.18$ \\
14 & linalool & 11.30 & 1095 & 1095 & $3.85 \pm 0.34$ \\
15 & 4-terpineol & 14.87 & 1130 & 1130 & $0.25 \pm 0.05$ \\
16 & $\alpha$-terpineol & 15.52 & 1131 & 1131 & $0.21 \pm 0.04$ \\
\hline
\end{tabular}


Table 1. Cont.

\begin{tabular}{cccccc}
\hline 17 & $\alpha$-copaene & 24.62 & 1374 & 1373 & $1.92 \pm 0.15$ \\
18 & $\alpha$-bourbonene & 25.06 & 1387 & 1387 & $0.36 \pm 0.05$ \\
19 & $\beta$-elemene & 25.48 & 1389 & 1388 & $4.94 \pm 0.35$ \\
20 & $\beta$-caryophyllene & 26.74 & 1417 & 1417 & $12.41 \pm 1.02$ \\
21 & $\alpha$-humulene & 28.36 & 1436 & 1436 & $2.52 \pm 0.20$ \\
22 & $\beta$-farnesene & 28.62 & 1440 & 1440 & $2.33 \pm 0.14$ \\
23 & aromadendrane & 28.72 & 1460 & 1559 & $0.64 \pm 0.11$ \\
24 & germacrene B & 29.52 & 1480 & 1480 & $1.07 \pm 0.29$ \\
25 & $\alpha$-amorphene & 29.71 & 1483 & 1483 & $0.90 \pm 0.13$ \\
26 & $\alpha$-selinene & 30.37 & 1498 & 1498 & $0.95 \pm 0.08$ \\
27 & $\beta$-bisabolene & 31.06 & 1505 & 1505 & $0.59 \pm 0.05$ \\
28 & $\gamma$-cadinene & 31.74 & 1513 & 1513 & $0.99 \pm 0.11$ \\
29 & $\alpha$-elemol & 32.91 & 1548 & 1548 & $0.96 \pm 0.09$ \\
30 & spathulenol & 34.18 & 1577 & 1577 & $1.29 \pm 0.15$ \\
31 & caryophyllene oxide & 34.41 & 1582 & 1582 & $3.19 \pm 0.31$ \\
32 & globulol & 34.81 & 1590 & 1590 & $0.65 \pm 0.12$ \\
33 & viridiflorol & 35.33 & 1592 & 1592 & $0.24 \pm 0.07$ \\
34 & salvial-4(14)-en-1-one & 35.60 & 1593 & 1593 & $0.34 \pm 0.09$ \\
35 & $\alpha$-cadinol & 37.30 & 1638 & 1638 & $0.38 \pm 0.08$ \\
36 & $\tau$-muurolol & 37.41 & 1643 & 1643 & $0.48 \pm 0.10$ \\
37 & $\beta$-eudesmol & 37.55 & 1649 & 1649 & $0.52 \pm 0.13$ \\
38 & $\alpha$-eudesmol & 37.61 & 1652 & 1652 & $0.48 \pm 0.11$ \\
39 & bulnesol & 48.93 & 1670 & 1670 & $4.37 \pm 0.48$ \\
40 & cembrene & 53.40 & 1937 & 1938 & $7.12 \pm 0.55$ \\
41 & thunbergol & 56.69 & 2061 & 2063 & $11.74 \pm 1.11$ \\
42 & geranyllinalool & 56.90 & 2125 & 2125 & $2.30 \pm 0.34$ \\
$\Sigma$ total identified & & & & $90.00 \%$ \\
\hline
\end{tabular}

a Retention indexes (RI) calculated with the Van den Dool and Kratz equation, ${ }^{\mathrm{b}}$ Main observed fragments and molecular mass (MM), ${ }^{\mathrm{C}}$ Proportional area relative to the total area of chromatogram after eliminating peaks arising of contamination and/or column bleeding.

\subsection{In Vitro Cytotoxicity}

In vitro cytotoxicity of the $\mathrm{EO}$ from the leaves of $C$. matourensis to human cancer cell lines MCF-7 (breast adenocarcinoma), HCT116 (colon carcinoma), HepG2 (hepatocellular carcinoma), HL-60 (promyelocytic leukemia), and human non-cancer cell line MRC-5 (lung fibroblasts) was assessed by the Alamar blue assay after $72 \mathrm{~h}$ of treatment. Table 2 presents the half maximal inhibitory concentrations $\left(\mathrm{IC}_{50}\right)$ obtained. The EO displayed an $\mathrm{IC}_{50}$ value of $23.3 \mu \mathrm{g} / \mathrm{mL}$ for MCF-7, $28.9 \mu \mathrm{g} / \mathrm{mL}$ for HCT116, $28.5 \mu \mathrm{g} / \mathrm{mL}$ for HepG2, $17.8 \mu \mathrm{g} / \mathrm{mL}$ for HL-60, and $25.8 \mu \mathrm{g} / \mathrm{mL}$ for MRC-5. Doxorubicin was used as the positive control and showed an $\mathrm{IC}_{50}$ value of $0.3 \mu \mathrm{g} / \mathrm{mL}$ for MCF-7, $0.1 \mu \mathrm{g} / \mathrm{mL}$ for HCT116, $0.03 \mu \mathrm{g} / \mathrm{mL}$ for HepG2, $0.04 \mu \mathrm{g} / \mathrm{mL}$ for HL-60, and $0.2 \mu \mathrm{g} / \mathrm{mL}$ for MRC-5.

Then, we quantified the cell viability using annexin V-FITC and PI double staining, and the cell fluorescence was measured by flow cytometry to determine the percentage of HepG2 cells in viable (cells that are annexin V-FITC/PI double-negative), early apoptotic (cells that are annexin V-FITC-positive and PI-negative), late apoptotic (cells that are annexin V-FITC/PI double-positive), and necrotic (cells that are annexin V-FITC-negative and PI-positive) stages after $48 \mathrm{~h}$ of treatment with the EO at concentrations of 12.5, 25, and $50 \mu \mathrm{g} / \mathrm{mL}$, as shown in Figure 1. These concentrations were based at the $\mathrm{IC}_{50}$ value $(28.5 \mu \mathrm{g} / \mathrm{mL})$ of the EO for HepG2 cells, and since the doubling time of HepG2 cell is about $48 \mathrm{~h}$, we used this time of treatment to evaluate the effect of the EO after one full cell cycle. The EO treatment caused an increase of the apoptotic (early + late apoptotic cells) cell death after $48 \mathrm{~h}$ of treatment $(P<0.05)$. No increase in the necrotic (annexin V-FITC-negative/PI-positive) cells was observed $(P>0.05)$. Doxorubicin also led to an increase of the apoptotic cells $(P<0.05)$. At the concentrations of $12.5,25$, and $50 \mu \mathrm{g} / \mathrm{mL}$, the EO increased the apoptotic cell death to $12.1 \%$, $23.6 \%$, and $25.7 \%$, against $6.3 \%$ observed at the control group. Doxorubicin, at $1 \mu \mathrm{g} / \mathrm{mL}$, increased the apoptosis to $20.7 \%$. 
Table 2. Half maximal inhibitory concentration $\left(\mathrm{IC}_{50}\right)$ values of the cytotoxic activity of the essential oil (EO) from the leaves of Croton matourensis.

\begin{tabular}{lcccc}
\hline \multicolumn{1}{c}{ Cell Lines } & Origin & Histological Type & \multicolumn{2}{c}{ IC $_{50}$ in $\mu \mathrm{g} / \mathrm{mL}$} \\
\hline Cancer cells & & & EO & DOX \\
MCF-7 & \multirow{2}{*}{ Human } & Breast adenocarcinoma & 23.3 & 0.3 \\
& & & $18.2-29.7$ & $0.2-0.4$ \\
HCT116 & Human & Colon carcinoma & 28.9 & 0.1 \\
& & Hepatocellular & 28.5 & $0.1-0.2$ \\
HepG2 & Human & carcinoma & $17.1-37.3$ & $0.01-0.2$ \\
& \multirow{2}{*}{ Human } & Promyelocytic & 17.8 & 0.04 \\
& & leukemia & $14.6-21.7$ & $0.02-0.08$ \\
\hline Non-cancer cell & & & & \\
MRC-5 & \multirow{2}{*}{ Human } & Lung fibroblast & 25.8 & 0.2 \\
& & & $22.0-30.4$ & $0.1-0.5$ \\
\hline
\end{tabular}

Data are presented as $\mathrm{IC}_{50}$ values, in $\mu \mathrm{g} / \mathrm{mL}$, with respective $95 \%$ confidence interval obtained by nonlinear regression from at least three independent experiments performed in duplicate, measured by Alamar blue assay after $72 \mathrm{~h}$ of treatment. Doxorubicin (DOX) was used as the positive control.

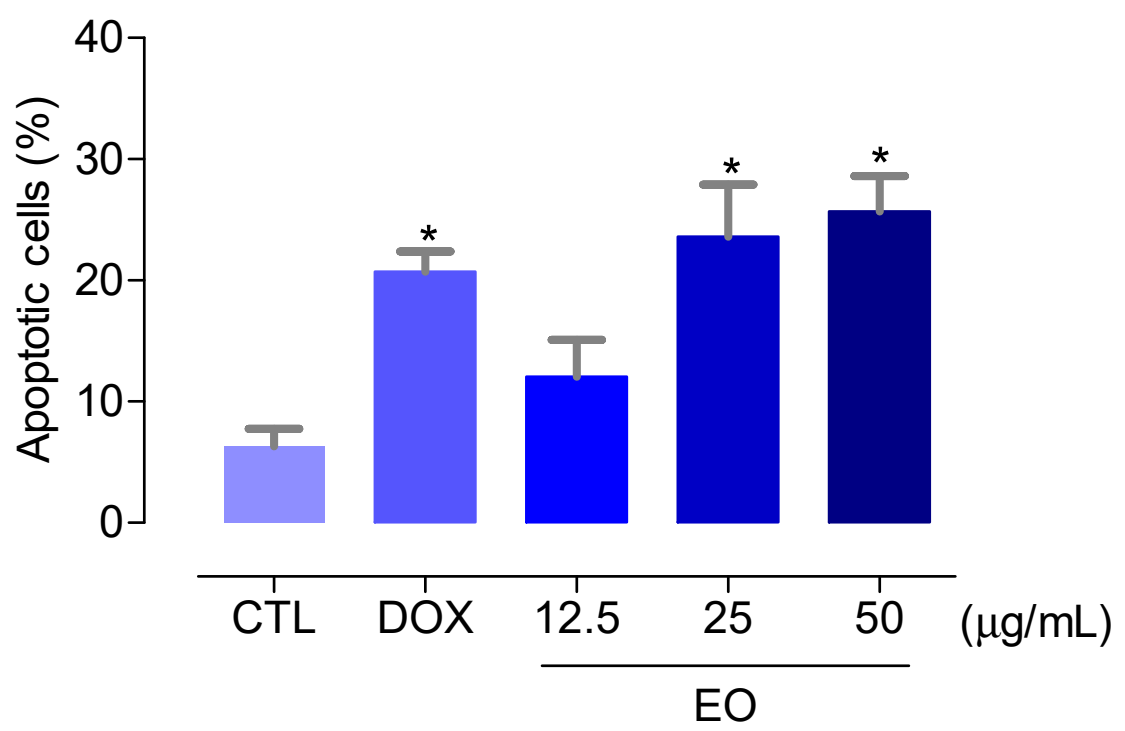

Figure 1. Effect of the essential oil (EO) from the leaves of Croton matourensis on the induction of apoptosis (early + late apoptotic cells) in HepG2 cells after 48 h of treatment, as determined by flow cytometry using annexin V-FITC/PI staining. The negative control (CTL) was treated with the vehicle (0.1\% DMSO) used for diluting the EO. Doxorubicin (DOX, $1 \mu \mathrm{g} / \mathrm{mL}$ ) was used as the positive control. Data are presented as the means \pm SEM. of three independent experiments performed in duplicate. Ten thousand events were evaluated per experiment, and cellular debris was omitted from the analysis. ${ }^{*} P<0.05$ compared with the negative control by ANOVA, followed by Bonferroni's multiple comparison test.

The cell cycle distribution in the EO-treated HepG2 cells was performed by the DNA content using flow cytometry after $48 \mathrm{~h}$ of treatment, as shown in Figure 2. All DNA that was sub-diploid in size (sub-G $\mathrm{G}_{0} / \mathrm{G}_{1}$ ) was considered fragmented. EO-treated HepG2 cells presented an internucleosomal DNA fragmentation significantly increased $(P<0.05)$. Doxorubicin also significantly induced internucleosomal DNA fragmentation $(P<0.05)$. At the concentrations of $12.5,25$, and $50 \mu \mathrm{g} / \mathrm{mL}$, the EO increased the DNA fragmentation to $10.0 \%, 13.2 \%$, and $40.5 \%$, against $7.0 \%$ observed at the control group. Doxorubicin, at $1 \mu \mathrm{g} / \mathrm{mL}$, increased the DNA fragmentation to $22.4 \%$. The cell cycle phases $\mathrm{G}_{0} / \mathrm{G}_{1}, \mathrm{~S}$, and $\mathrm{G}_{2} / \mathrm{M}$ were reduced proportionally. 

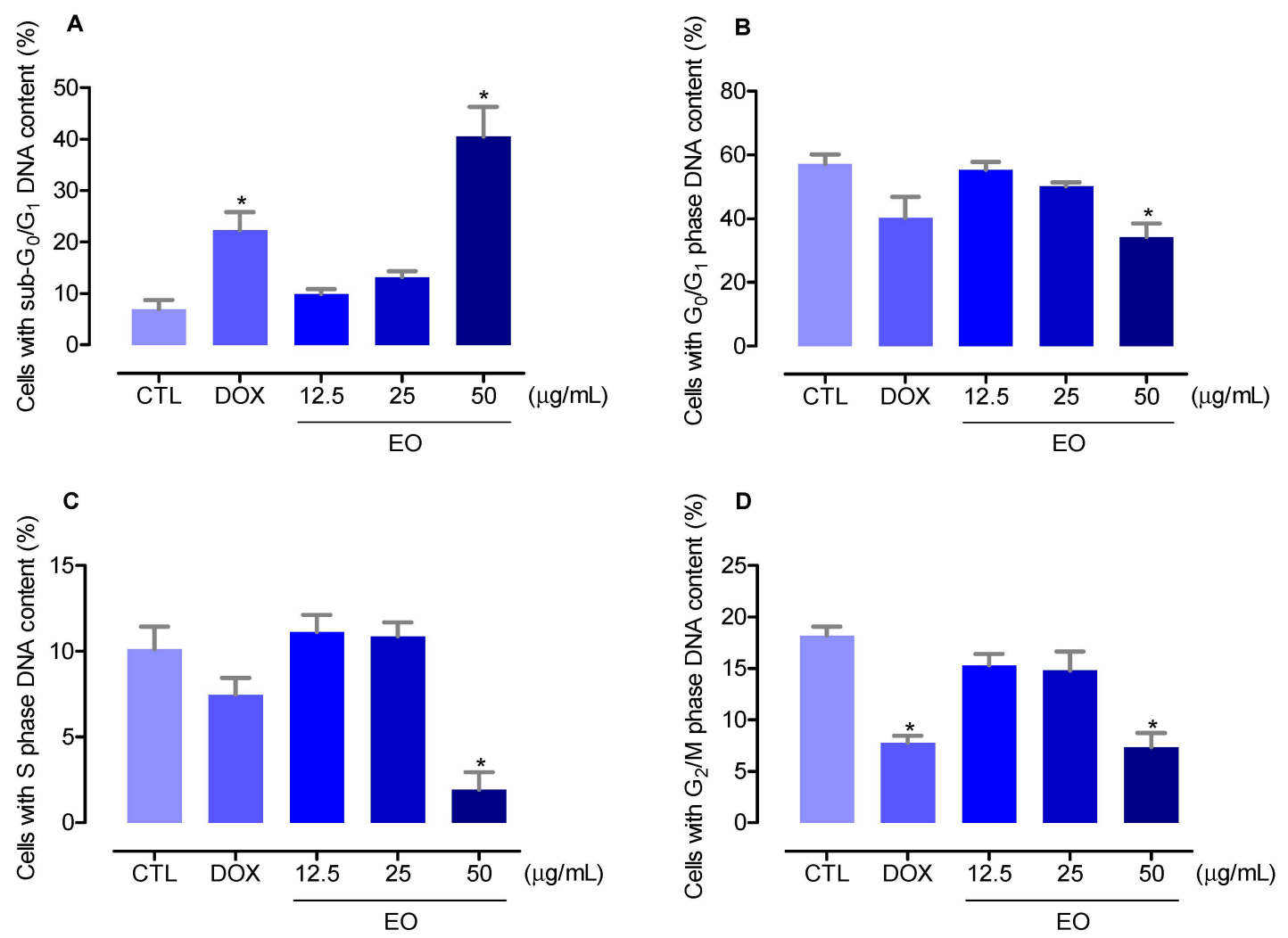

Figure 2. Effect of the essential oil (EO) from the leaves of Croton matourensis in the cell cycle distribution of HepG2 cells. (A) Percentage of cells with sub- $G_{0} / G_{1}$ DNA content (DNA fragmentation). (B) Percentage of cells with $G_{0} / G_{1}$ phase DNA content. (C) Percentage of cells with $S$ phase DNA content. (D) Percentage of cells with $\mathrm{G}_{2} / \mathrm{M}$ phase DNA content. The negative control (CTL) was treated with the vehicle (0.1\% DMSO) used for diluting the EO. Doxorubicin (DOX, $1 \mu \mathrm{g} / \mathrm{mL}$ ) was used as the positive control. Data are presented as the means \pm SEM. of three independent experiments performed in duplicate. Ten thousand events were evaluated per experiment, and cellular debris was omitted from the analysis. ${ }^{*} P<0.05$ compared with the negative control by ANOVA, followed by Bonferroni's multiple comparison test.

\subsection{In Vivo Antitumor Activity}

In vivo antitumor effect of the EO from the leaves of C. matourensis was assessed in C.B-17 severe combined immunodeficient (SCID) mice with HepG2 cell xenografts. Animals were treated with the $\mathrm{EO}$ at doses of 40 and $80 \mathrm{mg} / \mathrm{kg} /$ day through intraperitoneal injections delivered once a day for 21 consecutive days. At the end of the treatment, the mean tumor mass weight of the negative control animals was $0.5 \pm 0.1 \mathrm{~g}$, as shown in Figure 3A. In the EO-treated animals, the mean tumor mass weights were $0.3 \pm 0.1 \mathrm{~g}$ at $40 \mathrm{mg} / \mathrm{kg} /$ day dosage and $0.2 \pm 0.03 \mathrm{~g}$ at $80 \mathrm{mg} / \mathrm{kg} /$ day dosage. Tumor mass inhibition rates of the EO were $34.6 \%$ to $55.9 \%(P<0.05)$, as shown in Figure 3B. In this study, 5 -fluorouracil at the dosage of $10 \mathrm{mg} / \mathrm{kg} /$ day was used as the positive control, which reduced the tumor weight by $44.2 \%$. 


\section{A}

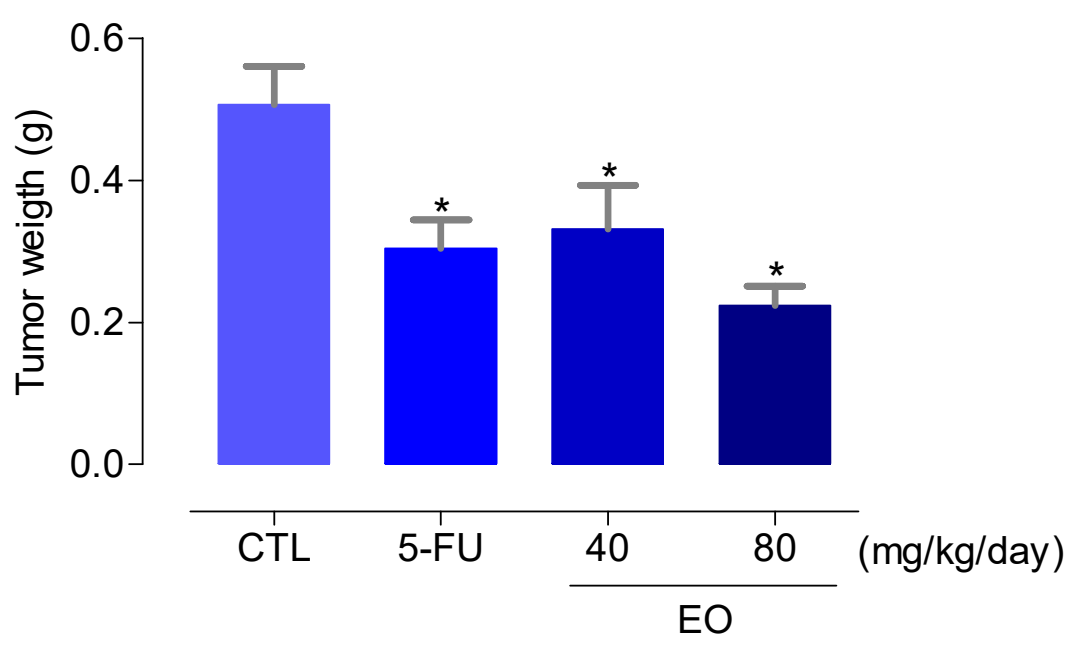

B

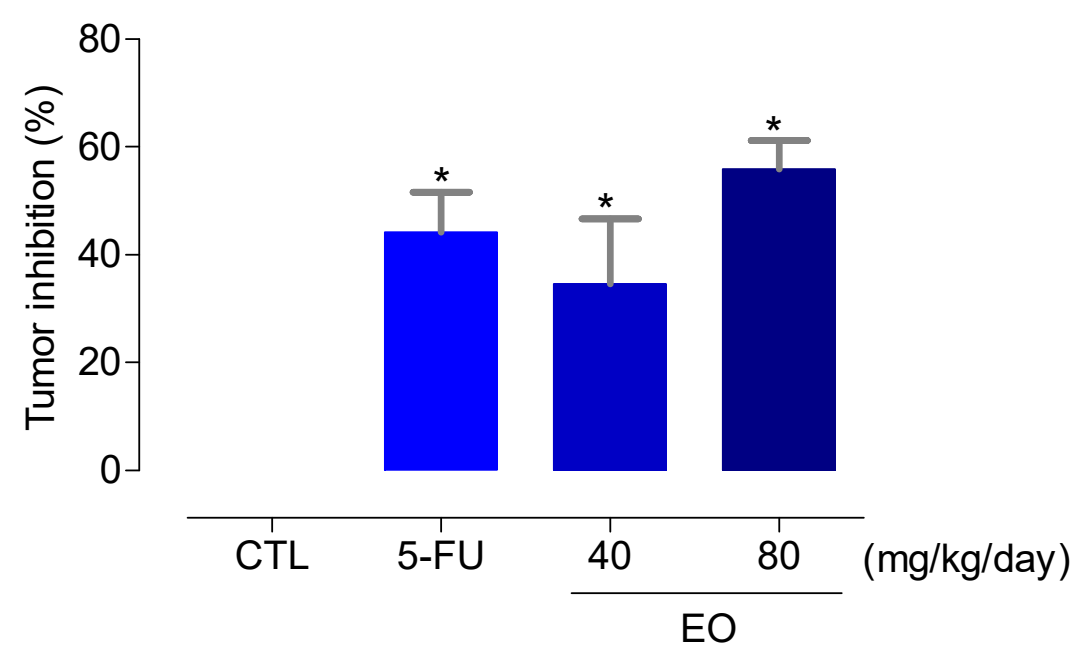

Figure 3. In vivo antitumor activity of the essential oil (EO) from the leaves of Croton matourensis in C.B-17 severe combined immunodeficient (SCID) mice with HepG2 cell xenografts. (A) Tumor weight (g) after treatment. (B) Tumor inhibition (\%) after treatment. Beginning 1 day after tumor implantation, the animals were treated through the intraperitoneal route for 21 consecutive days. The negative control (CTL) was treated with the vehicle (5\% DMSO) used for diluting the EO. 5-Fluorouracil (5-FU, $10 \mathrm{mg} / \mathrm{kg} /$ day) was used as the positive control. Data are presented as means $\pm \mathrm{SEM}$. of 10-20 animals. ${ }^{*} P<0.05$ compared to the negative control by ANOVA followed by Bonferroni's multiple comparison test.

In regard to the toxicological parameters investigated, no significant changes on body and organs (liver, kidney, lung, and heart) weight were seen on the EO-treated groups $(P>0.05)$, as shown in Table 3. Hematological parameters of the peripheral blood drawn from C.B-17 SCID mice with HepG2 cell xenografts were also analyzed, as shown in Table 4. Although some variations have been observed, no statistically significant alteration was found in the hematological parameters in the animals treated with the $\mathrm{EO}(P>0.05)$. 
Table 3. Effect of the essential oil (EO) from the leaves of Croton matourensis on body and relative organ weight from C.B-17 SCID mice with HepG2 cell xenografts.

\begin{tabular}{lcccc}
\hline \multicolumn{1}{c}{ Parameters } & CTL & 5-FU & \multicolumn{2}{c}{ EO } \\
\hline Dose (mg/kg/day) & - & 10 & 40 & 80 \\
Initial body weight (g) & $21.4 \pm 0.5$ & $19.6 \pm 0.6$ & $22.0 \pm 0.5$ & $19.9 \pm 0.6$ \\
Final body weight (g) & $22.1 \pm 0.5$ & $20.5 \pm 0.5$ & $21.0 \pm 0.3$ & $20.9 \pm 0.4$ \\
Liver (g/100 g body weight) & $4.8 \pm 0.2$ & $4.8 \pm 0.2$ & $5.0 \pm 0.3$ & $5.2 \pm 0.3$ \\
Kidney (g/100 g body weight) & $1.5 \pm 0.1$ & $1.5 \pm 0.1$ & $1.4 \pm 0.1$ & $1.5 \pm 0.1$ \\
Heart (g/100 g body weight) & $0.5 \pm 0.1$ & $0.6 \pm 0.1$ & $0.6 \pm 0.1$ & $0.5 \pm 0.1$ \\
Lung (g/100 g body weight) & $0.8 \pm 0.1$ & $0.8 \pm 0.1$ & $0.8 \pm 0.1$ & $0.7 \pm 0.1$ \\
\hline
\end{tabular}

Beginning 1 day after tumor implantation, the animals were treated through the intraperitoneal route for 21 consecutive days. The negative control (CTL) was treated with the vehicle (5\% DMSO) used for diluting the EO. 5-Fluorouracil (5-FU, $10 \mathrm{mg} / \mathrm{kg} /$ day) was used as the positive control. Data are presented as means $\pm \mathrm{SEM}$. of 10-20 animals.

Table 4. Effect of the essential oil (EO) from the leaves of Croton matourensis on hematological parameters of peripheral blood from C.B-17 SCID mice with HepG2 cell xenografts.

\begin{tabular}{lcccc}
\hline \multicolumn{1}{c}{ Parameters } & CTL & 5-FU & \multicolumn{2}{c}{ EO } \\
\hline Dose $(\mathrm{mg} / \mathrm{kg} /$ day) & - & 10 & 40 & 80 \\
Erythrocytes $\left(10^{6} / \mathrm{mm}^{3}\right)$ & $5.2 \pm 1.1$ & $7.6 \pm 0.8$ & $4.9 \pm 1.2$ & $7.6 \pm 1.1$ \\
Hemoglobin $(\mathrm{g} / \mathrm{dL})$ & $21.2 \pm 4.8$ & $17.7 \pm 3.1$ & $26.9 \pm 0.7$ & $17.7 \pm 2.2$ \\
Hematocrit $(\%)$ & $22.0 \pm 4.7$ & $38.9 \pm 0.3$ & $9.5 \pm 0.3$ & $40.1 \pm 1.4$ \\
MCV (fL) & $43.8 \pm 0.4$ & $45.0 \pm 3.0$ & $42.0 \pm 0.0$ & $45.3 \pm 0.5$ \\
Platelets $\left(10^{3} / \mathrm{mm}^{3}\right)$ & $247.2 \pm 38.5$ & $222.1 \pm 41.6$ & $519.3 \pm 136.6$ & $279.7 \pm 37.2$ \\
Leukocytes $\left(10^{3} / \mathrm{mm}^{3}\right)$ & $5.2 \pm 0.8$ & $2.5 \pm 0.6$ & $7.1 \pm 0.6$ & $3.5 \pm 0.5$ \\
Differential leukocytes $(\%)$ & & & & \\
Granulocytes & 24.1 & 28.4 & 26.8 & 26.7 \\
Lymphocytes & 41.5 & 46.1 & 45.4 & 51.7 \\
Monocytes & 33.6 & 25.5 & 27.8 & 21.7
\end{tabular}

Beginning 1 day after tumor implantation, the animals were treated through the intraperitoneal route for 21 consecutive days. The negative control (CTL) was treated with the vehicle (5\% DMSO) used for diluting the EO. 5-Fluorouracil (5-FU, $10 \mathrm{mg} / \mathrm{kg} /$ day) was used as the positive control. Data are presented as means \pm SEM. of 7-14 animals. MCV: Mean corpuscular volume.

\section{Discussion}

In this study, antitumor effect of the EO from the leaves of $C$. matourensis was reported for the first time at this communication. As mentioned above, a previous study investigated the chemical composition and cytotoxic activity of the EO from the leaves of C. matourensis collected in Venezuela [19]. These authors found fenchyl acetate, methyleugenol, isoelemicine, elemicine, spathulenol, and valencene as the main constituents of this EO. Moreover, previous studies with the EO from the leaves, fruit, inflorescence, and bark of $C$. matourensis collected from the Brazilian Amazon rainforest presented $\alpha$-pinene, elemecine, $\alpha$-phellandrene, $p$-cymene, linalool, and $\beta$-caryophyllene as the main constituents $[16,17]$. Herein, we observed a different chemical composition of the EO for $C$. matourensis in comparison with individuals collected in Venezuela, where $\beta$-caryophyllene, thunbergol, cembrene, $p$-cymene, and $\beta$-elemene were found as major constituents. Interestingly, when compared to with a specimen collected in central Amazonia, especially, in Brazil, a similar chemical composition is observed.

In the work of Compagnone et al. [19], the $\mathrm{EO}$ from the leaves of C. matourensis caused cytotoxicity in LoVo (human colon carcinoma) and HeLa (human cervical cancer) cell lines with $\mathrm{IC}_{50}$ values of 36.6 and $83.9 \mu \mathrm{g} / \mathrm{mL}$, respectively, while inducing cytotoxicity in human dermis fibroblasts cells with an $\mathrm{IC}_{50}$ value of $132.7 \mu \mathrm{g} / \mathrm{mL}$. In this work, we observed similar results where the EO was cytotoxic with $\mathrm{IC}_{50}$ values of $23.3 \mu \mathrm{g} / \mathrm{mL}$ for MCF-7, $28.9 \mu \mathrm{g} / \mathrm{mL}$ for HCT116, $28.5 \mu \mathrm{g} / \mathrm{mL}$ for HepG2, $17.8 \mu \mathrm{g} / \mathrm{mL}$ for HL-60, and $25.8 \mu \mathrm{g} / \mathrm{mL}$ for MRC-5. 
In our cytotoxic screening program, EO with $\mathrm{IC}_{50}$ values below $30 \mu \mathrm{g} / \mathrm{mL}$ are considered promising for cancer drug development [20-22]. Therefore, the results obtained with the EO from the leaves of $C$. matourensis should be explored further. These data corroborate with previous results observed with EO obtained from Croton species. The EO from the leaves of $C$. flavens showed cytotoxicity in A-549 (human lung carcinoma) and DLD-1 (human colon adenocarcinoma) cells with $\mathrm{IC}_{50}$ values of 27 and $28 \mu \mathrm{g} / \mathrm{mL}$, respectively [23]. The EO from the leaves of C. regelianus induced cytotoxic effect in HL-60, HCT-8 (human colon carcinoma), SF295 (human glioblastoma), MDA-MB-435 (human melanoma) cells, with $\mathrm{IC}_{50}$ values of $22.2,40.0,48.0$, and $47.3 \mu \mathrm{g} / \mathrm{mL}$, respectively [6]. The EO obtained from leaves of $C$. campestres exhibited cytotoxicity in MCF-7 and HT-29 (human colon adenocarcinoma) cells with $\mathrm{IC}_{50}$ values of 8.61 and $9.94 \mu \mathrm{g} / \mathrm{mL}$, respectively [24].

Concerning the main constituents of the EO from the leaves of $C$. matourensis, some of them, e.g., $\beta$-caryophyllene, cembrene, $p$-cymene, and $\beta$-elemene, have been reported as cytotoxic agents $[22,25-28]$, indicating that the mixture of them are associated with the cytotoxic and antitumor properties of this EO.

Phosphatidylserine externalization and DNA fragmentation, without loss of the cell membrane integrity, are cellular biochemical alterations that are often correlated with the apoptotic cell death [29]. Herein, we observed that the EO from the leaves of $C$. matourensis increased the phosphatidylserine exposure and internucleosomal DNA, without causing alterations in the cell membrane integrity (no increase in the PI-positive cells was observed). Moreover, the EO from the leaves of Lippia gracilis, Guatteria blepharophylla, and Guatteria hispida inhibited cell proliferation and induced cell death by apoptosis in HepG2 cells [25,30]. The EO from the aerial parts of Salvia aurea, S. judaica, and S. viscosa caused the apoptosis process and increasing reactive oxygen species in DU-145 (human prostate cancer) cells [31]. The EO from the leaves of Pinus roxburghii induced apoptosis along with inhibition of NF- $k \mathrm{~B}$ and inhibited the expression of genes associated to cell survival (survivin, c-FLIP, Bcl-2, Bcl-xL, c-Myc, c-IAP2), proliferation (cyclin D1), and metastasis (MMP-9) in KBM-5 (chronic myeloid leukemia) cells [32].

In addition, we demonstrated that the $\mathrm{EO}$ from the leaves of $C$. matourensis has in vivo antitumor effect in C.B-17 SCID mice with HepG2 cell xenografts. The antitumor effect of the EO from the leaves of $C$. regelianus has been previously reported using sarcoma 180 as tumor model, while the EO inhibited the tumor development by $28.1 \%$ and $31.8 \%$, at doses of 50 and $100 \mathrm{mg} / \mathrm{kg} /$ day, and the ascaridole, one of its main constituents, inhibited the tumor development by $33.9 \%$ and $33.3 \%$, at doses of 10 and $20 \mathrm{mg} / \mathrm{kg} /$ day, respectively [6]. Herein, the EO from the leaves of $C$. matourensis inhibited the tumor mass by $34.6 \%$ to $55.9 \%$ at doses of 40 and $80 \mathrm{mg} / \mathrm{kg} /$ day, respectively, and although the EO was less potent than the positive control 5-fluorouracil, the EO presented similar or superior efficacy to that observed for it. The positive control 5 -fluorouracil inhibited the tumor mass by $44.2 \%$ at a dose of $10 \mathrm{mg} / \mathrm{kg} /$ day.

In conclusion, the EO from the leaves of $C$. matourensis has $\beta$-caryophyllene, thunbergol, cembrene, $p$-cymene, and $\beta$-elemene as major constituents. Moreover, the $\mathrm{EO}$ has an in vitro and in vivo anti-liver cancer effect. These data indicate the anticancer potential effect of this plant.

\section{Material and Methods}

\subsection{Botanical Material}

Leaves from the species C. matourensis were collected in March 2014 in the green area of the Adolpho Ducke botanical garden at the Amazonia Museum (MUSA) $\left(3^{\circ} 01^{\prime} 12.8^{\prime \prime} \mathrm{S}, 59^{\circ} 56^{\prime} 23.2^{\prime \prime} \mathrm{W}\right)$ from a specimen previously identified by N.M.D. Cardozo and catalogued (\#492).

\subsection{Essential Oil Extraction}

After collection, the aerial parts were directly extracted by hydrodistillation in a Clevenger-type apparatus. For this, $300 \mathrm{~g}$ of fresh and crushed material was extracted for a period of $4 \mathrm{~h}$ in $1000 \mathrm{~mL}$ of 
ultrapure water $\left(18.2 \mathrm{M} \Omega\right.$ ). Then, the obtained oils were extracted with $\mathrm{CH}_{2} \mathrm{Cl}_{2}$, dried over anhydrous $\mathrm{Na}_{2} \mathrm{SO}_{4}$ and filtered through a nylon membrane (pore size $0.22 \mu \mathrm{m}$, Whatman, Maidstone, UK). The resulting EO were weighed in vials and stored at $-4{ }^{\circ} \mathrm{C}$ prior to chemical analysis.

\subsection{Chemical Analysis}

The qualitative analysis was performed by gas chromatography coupled to mass spectrometry (GC-MS) with an equipment model GCMS/QP2010 Plus (Shimadzu, Kyoto, Japan) using a selective detector and a capillary column Rtx-5 MS (30 m $\times 0.25 \mathrm{~mm} \times 0.25$, Restek). Helium was used as carrier gas with a flow of $1.02 \mathrm{~mL} / \mathrm{min}$. Injections $(1 \mu \mathrm{L})$ were performed with EO solutions at $2 \mathrm{mg} / \mathrm{mL}$ in $\mathrm{CH}_{2} \mathrm{Cl}_{2}$ using a split ratio of 1:50. The column temperature program was 60 to $280{ }^{\circ} \mathrm{C}$ with gradual increase of $3{ }^{\circ} \mathrm{C} / \mathrm{min}$. The temperatures of the injector and the ion source were $220^{\circ} \mathrm{C}$ and $260^{\circ} \mathrm{C}$, respectively. Preliminary identifications of the constituents were performed based on comparison of experimental spectra with those stored in the Wiley 8th edition library (similarities $>90 \%$ ). The confirmation of the identifications was performed by the calculation of the retention indexes (RI) according to the Van den Dool and Kratz equation [33] in comparison to a homologous series of linear hydrocarbons (C7-C30). A semi-quantitative analysis was performed to obtain the relative amount of each component of the EO. For this procedure, a gas chromatography with flame ionization detection (GC-FID) system, model GC2010 (Shimadzu) equipped with a Rtx-5 capillary column, was used. The same conditions of the GC-MS analysis were employed to ensure reproducibility. Relative amounts (\%) were calculated in relation to the total area of the chromatogram.

\subsection{In Vitro Assays}

\subsubsection{Cells}

Human cancer cell lines MCF-7 (breast adenocarcinoma), HCT116 (colon carcinoma), HepG2 (hepatocellular carcinoma), HL-60 (promyelocytic leukemia), and human non-cancer cell line MRC-5 (lung fibroblast) were obtained from the American Type Culture Collection (ATCC, Manassas, VA, USA). The cells were cultured as recommended by the ATCC. Cell viability was examined via trypan blue exclusion method for all experiments.

\subsubsection{Cell Viability Assay}

Cell viability was measured by the Alamar blue assay and was performed as previously described [34-36]. For all experiments, cells were plated in 96-well plates. The EO was dissolved in dimethyl sulfoxide (DMSO, Vetec Química Fina Ltd., Duque de Caxias, RJ, Brazil) and added to each well and incubated for $72 \mathrm{~h}$. Doxorubicin (purity $\geq 95 \%$, doxorubicin hydrochloride, Laboratory IMA S.A.I.C., Buenos Aires, Argentina) was used as the positive control. At the end of the treatment, $20 \mu \mathrm{L}$ of a stock solution $(0.312 \mathrm{mg} / \mathrm{mL}$ ) of resazurin (Sigma-Aldrich Co., Saint Louis, MO, USA) was added to each well. Absorbances at 570 and $600 \mathrm{~nm}$ were measured using a SpectraMax 190 Microplate Reader (Molecular Devices, Sunnyvale, CA, USA).

\subsubsection{Annexin-V/PI Staining Assay}

For apoptosis quantification, FITC Annexin V Apoptosis Detection Kit I (BD Biosciences, San Jose, CA, USA) was used, and the analysis performed according to the manufacturer's instructions. Cell fluorescence was measured by flow cytometry with a BD LSRFortessa cytometer. For flow cytometry analyses, $10^{4}$ events were recorded per sample with the BD FACSDiva Software (BD Biosciences) and Flowjo Software 10 (Flowjo LLC, Ashland, OR, USA). Cellular debris was omitted from the analysis. 


\subsubsection{Internucleosomal DNA Fragmentation and Cell Cycle Distribution}

The internucleosomal DNA fragmentation and cell cycle distributions were determined using propidium iodide (PI) (Sigma-Aldrich Co. St. Louis, MO, USA) in permeabilized cells, and performed as previously described [37]. Cell fluorescences were measured by flow cytometry as described above.

\subsection{In Vivo Assays}

\subsubsection{Animals}

A total of 50 C.B-17 severe combined immunodeficient (SCID) mice (females, 25-30 g) were obtained and maintained at Gonçalo Moniz Institute-FIOCRUZ animal facilities (Salvador, Bahia, Brazil). Animals were housed in cages with free access to food and water. All animals were subjected to a 12:12 h light-dark cycle (lights on at 6:00 a.m.). A local animal ethics committee approved the experimental protocol employed (number \#06/2015).

\subsubsection{Human Hepatocellular Carcinoma Xenograft Model}

HepG2 cells $\left(10^{7}\right.$ cells per $\left.500 \mu \mathrm{L}\right)$ were implanted subcutaneously into the left front armpits of the mice. At the beginning of the experiment, mice were randomly divided into four groups. Group 1: animals received injections of vehicle with 5\% DMSO solution $(n=20)$. Group 2: animals received injections of 5-fluorouracil $(10 \mathrm{mg} / \mathrm{kg} /$ day, Sigma-Aldrich, $n=10)$. Group 3: animals received injections of the EO at $40 \mathrm{mg} / \mathrm{kg} /$ day $(n=10)$. Group 4: animals received injections of the EO at $80 \mathrm{mg} / \mathrm{kg} /$ day $(n=10)$. These dosages were selected based on previous works using EO in tumor models in mice $[25,38]$. Beginning 1 day after tumor implantation, the animals were treated through the intraperitoneal route for 21 consecutive days. One day after the end of the treatment, animals were anesthetized, and peripheral blood samples were collected from the brachial artery. Animals were euthanized by anesthetic overdose, and tumors were excised and weighed.

\subsubsection{Toxicological Evaluation}

The mice were weighed at the beginning and end of the experiment to evaluate the toxicological effects. Animals were observed for signs of abnormality throughout the study. A hematological analysis was performed using the Advia 60 hematology system (Bayer, Leverkusen, Germany). Livers, kidneys, lungs, and hearts were removed, weighed, and examined for signs of gross lesion formation, color change, and/or hemorrhaging.

\subsection{Statistical Analysis}

Data were presented as means \pm standard error of the mean (SEM) or as $\mathrm{IC}_{50}$ values with $95 \%$ confidence intervals obtained by nonlinear regressions. Differences among the experimental groups were compared through analysis of variance (ANOVA) followed by Bonferroni's multiple comparison test $(P<0.05)$. All statistical analyses were performed using GraphPad Prism (Intuitive Software for Science; San Diego, CA, USA).

Author Contributions: Conceived and designed the experiments: H.H.F.K. and D.P.B. Collected the plant material and performed the chemical experiments: E.J.S.P.d.L., G.M.A.D., N.M.D.C., E.V.C., F.M.A.d.S., and H.H.F.K. Performed the in vitro and in vivo experiments: R.G.A., T.A.d.A., V.R.S., and L.d.S.S. Analyzed the data: J.S.P.L., G.M.A.D., N.M.D.C., E.V.C., F.M.A.d.S., H.H.F.K., R.G.A., T.A.d.A., V.R.S., L.d.S.S., M.B.P.S., and D.P.B. Contributed reagents/materials/analysis tools: M.B.P.S., H.H.F.K., and D.P.B. Wrote the paper: H.H.F.K. and D.P.B.

Acknowledgments: The authors are grateful to the flow cytometry core of FIOCRUZ-Bahia for collecting the flow cytometric data. This work was financially supported by Brazilian agencies Coordenação de Aperfeiçoamento de Pessoal de Nível Superior (CAPES), Conselho Nacional de Desenvolvimento Científico e Tecnológico (CNPq), Fundação de Amparo à Pesquisa do Estado do Amazonas (FAPEAM), and Fundação de Amparo à Pesquisa do Estado da Bahia (FAPESB).

Conflicts of Interest: The authors have no conflicts of interest to declare. 


\section{References}

1. Xu, W.H.; Liu, W.Y.; Liang, Q. Chemical constituents from Croton species and their biological activities. Molecules 2018, 23. [CrossRef] [PubMed]

2. Itokawa, H.; Ichihara, Y.; Mochizuki, M.; Enomori, T.; Morita, H.; Shirota, O.; Inamatsu, M.; Takeya, K. A cytotoxic substance from Sangre de Grado. Chem. Pharm. Bull. 1991, 39, 1041-1042. [CrossRef] [PubMed]

3. Sandoval, M.; Okuhama, N.N.; Clark, M.; Angeles, F.M.; Lao, J.; Bustamante, S.; Miller, M.J. Sangre de grado Croton palanostigma induces apoptosis in human gastrointestinal cancer cells. J. Ethnopharmacol. 2002, 80, 121-129. [CrossRef]

4. Chen, Z.P.; Cai, Y.; Phillipson, J.D. Studies on the anti-tumour, anti-bacterial, and wound-healing properties of dragon's blood. Planta Med. 1994, 60, 541-545. [CrossRef] [PubMed]

5. Kupchan, S.M.; Uchida, I.; Branfman, A.R.; Dailey, R.G.; Fei, B.Y. Antileukemic principles isolated from euphorbiaceae plants. Science 1976, 191, 571-572. [CrossRef] [PubMed]

6. Bezerra, D.P.; Marinho-Filho, J.D.; Alves, A.P.; Pessoa, C.; Moraes, M.O.; Pessoa, O.D.; Torres, M.C.; Silveira, E.R.; Viana, F.A.; Costa-Lotufo, L.V. Antitumor activity of the essential oil from the leaves of Croton regelianus and its component ascaridole. Chem. Biodivers. 2009, 6, 1224-1231. [CrossRef] [PubMed]

7. Alonso-Castro, A.J.; Ortiz-Sánchez, E.; Domínguez, F.; López-Toledo, G.; Chávez, M.; Ortiz-Tello, A.J.; García-Carrancá, A. Antitumor effect of Croton lechleri Mull. Arg. (Euphorbiaceae). J. Ethnopharmacol. 2012, 140, 438-442. [CrossRef] [PubMed]

8. Cândido-Bacani, P.M.; Figueiredo, P.O.; Matos, M.F.; Garcez, F.R.; Garcez, W.S. Cytotoxic orbitide from the latex of Croton urucurana. J. Nat. Prod. 2015, 78, 2754-2760. [CrossRef] [PubMed]

9. Coelho, P.L.; Oliveira, M.N.; Silva, A.B.; Pitanga, B.P.; Silva, V.D.; Faria, G.P.; Sampaio, G.P.; Costa, M.F.; Braga-de-Souza, S.; Costa, S.L. The flavonoid apigenin from Croton betulaster Mull inhibits proliferation, induces differentiation and regulates the inflammatory profile of glioma cells. Anticancer Drugs 2016, 27, 960-969. [CrossRef] [PubMed]

10. Du, Q.; Zhao, Y.; Liu, H.; Tang, C.; Zhang, M.; Ke, C.; Ye, Y. Isolation and structure characterization of cytotoxic phorbol esters from the seeds of Croton tiglium. Planta Med. 2017, 83, 1361-1367. [CrossRef] [PubMed]

11. Yuan, Q.Q.; Tang, S.; Song, W.B.; Wang, W.Q.; Huang, M.; Xuan, L.J. Crassins A-H, diterpenoids from the roots of Croton crassifolius. J. Nat. Prod. 2017, 80, 254-260. [CrossRef] [PubMed]

12. Costa, J.R.; Mitja, D. Use of vegetal resources by family farmers in Manacapuru, Amazonas state. Acta Amaz. 2010, 40, 49-58. [CrossRef]

13. Rodrigues, L. Inventory, Valorization of Forest Resources and Dynamics of Fragmentation in the Region of Influence of Juruena National Park, Mato Grosso. Ph.D. Thesis, Postgraduate Program in Ecology and Conservation, Universidade do Estado de Mato Grosso, Nova Xavantina, Brazil, 2013. (In Portuguese)

14. Trindade, M.J.S.; Lameira, O.A. Species from the Euphorbiaceae family used for medicinal purposes in Brazil. Rev. Cubana Plan. Medicinales 2014, 19, 292-309.

15. Cruz-Silva, S.C.B. Biodiversity History and Use in the Rural Black Community Quilombola Buriti Farm, Campo Grande, Mato Grosso Do Sul, Brazil. Ph.D. Thesis, Postgraduate Program in Environment and Regional Development, Universidade Anhanguera, Campo Grande, MS, Brazil, 2016. (In Portuguese)

16. Gottlieb, O.R.; Koketsu, M.; Magalhães, M.T.; Maia, J.G.S.; Mendes, P.H.; Rocha, A.I.; Silva, M.L.; Wiiberg, V.C. Óleos essenciais da Amazônia VII. Acta Amaz. 1981, 11, 143-148. [CrossRef]

17. Leão, I.M.S.; Andrade, C.H.S.; Pinheiro, M.L.B.; Rocha, A.F.I.; Machado, M.I.L.; Craveiro, A.A.; Alencar, J.W.; Matos, F.J.A. Essential oil of Croton lanjouwensis Jablonski from brazilian amazonian region. J. Essent. Oil Res. 1998, 10, 643-644. [CrossRef]

18. Schneider, C.; Breitmaier, E.; Bayma, J.; Franca, L.F.; Kneifel, H.; Krebs, H.C. Maravuic acid, a new seco-labdane diterpene from Croton matourensis. Liebigs Ann. 1995, 709-710. [CrossRef]

19. Compagnone, R.S.; Chavez, K.; Mateu, E.; Orsini, G.; Arvelo, F.; Suárez, A.I. Composition and cytotoxic activity of essential oils from Croton matourensis and Croton micans from Venezuela. Rec. Nat. Prod. 2010, 4, 101-108.

20. Silva, T.B.; Costa, C.O.; Galvão, A.F.; Bomfim, L.M.; Rodrigues, A.C.; Mota, M.C.; Dantas, A.A.; Santos, T.R.; Soares, M.B.; Bezerra, D.P. Cytotoxic potential of selected medicinal plants in northeast Brazil. BMC Complement. Altern. Med. 2016, 16, 199. [CrossRef] [PubMed] 
21. Bomfim, L.M.; Menezes, L.R.; Rodrigues, A.C.; Dias, R.B.; Rocha, C.A.; Soares, M.B.; Neto, A.F.; Nascimento, M.P.; Campos, A.F.; Silva, L.C.; et al. Antitumour activity of the microencapsulation of Annona vepretorum essential oil. Basic Clin. Pharmacol. Toxicol. 2016, 118, 208-213. [CrossRef] [PubMed]

22. Costa, E.V.; Menezes, L.R.; Rocha, S.L.; Baliza, I.R.; Dias, R.B.; Rocha, C.A.; Soares, M.B.; Bezerra, D.P. Antitumor properties of the leaf essential oil of Zornia brasiliensis. Planta Med. 2015, 81, 563-567. [CrossRef] [PubMed]

23. Sylvestre, M.; Pichette, A.; Longtin, A.; Nagau, F.; Legault, J. Essential oil analysis and anticancer activity of leaf essential oil of Croton flavens L. from Guadeloupe. J. Ethnopharmacol. 2006, 103, 99-102. [CrossRef] [PubMed]

24. Monteiro, P.A.; Zelioli, I.A.M.; Sousa, I.M.O.; Ruiz, A.L.T.G.; Vendramini-Costa, D.B.; Foglio, M.A.; Carvalho, J.E. Chemical composition and antiproliferative activity of Croton campestris A.St.-Hil. essential oil. Nat. Prod. Res. 2017, 9, 1-4. [CrossRef] [PubMed]

25. Ferraz, R.P.; Bomfim, D.S.; Carvalho, N.C.; Soares, M.B.; Silva, T.B.; Machado, W.J.; Prata, A.P.; Costa, E.V.; Moraes, V.R.; Nogueira, P.C.; et al. Cytotoxic effect of leaf essential oil of Lippia gracilis Schauer (Verbenaceae). Phytomedicine 2013, 20, 615-621. [CrossRef] [PubMed]

26. Al-Footy, K.O.; Alarif, W.M.; Zubair, M.S.; Ghandourah, M.A.; Aly, M.M. Antibacterial and cytotoxic properties of isoprenoids from the red sea soft coral, Lobophytum sp. Trop. J. Pharm. Res. 2016, 15, 1431-1438. [CrossRef]

27. Fidyt, K.; Fiedorowicz, A.; Strządała, L.; Szumny, A. $\beta$-caryophyllene and $\beta$-caryophyllene oxide-natural compounds of anticancer and analgesic properties. Cancer Med. 2016, 5, 3007-3017. [CrossRef] [PubMed]

28. Jiang, Z.; Jacob, J.A.; Loganathachetti, D.S.; Nainangu, P.; Chen, B. $\beta$-Elemene: Mechanistic studies on cancer cell interaction and its chemosensitization effect. Front. Pharmacol. 2017, 8, 105. [CrossRef] [PubMed]

29. Galluzzi, L.; Vitale, I.; Aaronson, S.A.; Abrams, J.M.; Adam, D.; Agostinis, P.; Alnemri, E.S.; Altucci, L.; Amelio, I.; Andrews, D.W.; et al. Molecular mechanisms of cell death: Recommendations of the nomenclature committee on cell death 2018. Cell Death Differ. 2018, 25, 486-541. [CrossRef] [PubMed]

30. Ferraz, R.P.C.; Bomfim, D.S.; Carvalho, N.C.; Soares, M.B.P.; Pinheiro, M.L.B.; Costa, E.V.; Bezerra, D.P. Cytotoxic properties of the leaf essential oils of Guatteria blepharophylla and Guatteria hispida (Annonaceae). Flavour Fragr J. 2014, 29, 228-232. [CrossRef]

31. Russo, A.; Cardile, V.; Graziano, A.C.E.; Avola, R.; Bruno, M.; Rigano, D. Involvement of Bax and Bcl-2 in induction of apoptosis by essential oils of three Lebanese Salvia species in human prostate cancer cells. Int. J. Mol. Sci. 2018, 19, E292. [CrossRef] [PubMed]

32. Sajid, A.; Manzoor, Q.; Iqbal, M.; Tyagi, A.K.; Sarfraz, R.A.; Sajid, A. Pinus Roxburghii essential oil anticancer activity and chemical composition evaluation. EXCLI J. 2018, 17, 233-245. [PubMed]

33. Van Den Dool, H.; Kratz, P.D. A generalization of the retention index system including linear temperature programmed gas-liquid partition chromatography. J. Chromatogr. A 1963, 11, 463-471. [CrossRef]

34. Ahmed, S.A.; Gogal, R.M., Jr.; Walsh, J.E. A new rapid and simple non-radioactive assay to monitor and determine the proliferation of lymphocytes: An alternative to $\left[{ }^{3} \mathrm{H}\right]$-thymidine incorporation assay. J. Immunol. Methods 1994, 170, 211-224. [CrossRef]

35. Santos, L.S.; Silva, V.R.; Menezes, L.R.A.; Soares, M.B.P.; Costa, E.V.; Bezerra, D.P. Xylopine induces oxidative stress and causes $\mathrm{G}_{2} / \mathrm{M}$ phase arrest, triggering caspase-mediated apoptosis by p53-independent pathway in HCT116 cells. Oxid. Med. Cell. Longev. 2017, 2017, 7126872. [CrossRef] [PubMed]

36. Silva, V.R.; Corrêa, R.S.; Santos, L.S.; Soares, M.B.P.; Batista, A.A.; Bezerra, D.P. A ruthenium-based 5-fluorouracil complex with enhanced cytotoxicity and apoptosis induction action in HCT116 cells. Sci. Rep. 2018, 8, 288. [CrossRef] [PubMed]

37. Nicoletti, I.; Migliorati, G.; Pagliacci, M.C.; Grignani, F.; Riccardi, C. A rapid and simple method for measuring thymocyte apoptosis by propidium iodide staining and flow cytometry. J. Immunol. Methods 1991, 139, 271-279. [CrossRef]

38. Rodrigues, A.C.; Bomfim, L.M.; Neves, S.P.; Menezes, L.R.; Dias, R.B.; Soares, M.B.; Prata, A.P.; Rocha, C.A.; Costa, E.V.; Bezerra, D.P. Antitumor properties of the essential oil from the leaves of Duguetia gardneriana. Planta Med. 2015, 81, 798-803.

Sample Availability: Sample of the EO is not available from the authors. 